\title{
Everyday Religious Practice
}

\section{Religious Practice and Domestic Surroundings}

Soja was a lively 80-year-old woman from Lahti, a large town about a hundred kilometers north of Helsinki. She lived in a slightly rundown wooden house, one of the so-called veterans' homes, detached houses of a standard model built by the thousands in the first years after the Second World War. She and her late husband had not built the house themselves, but had moved there in the 1950's. When I arrived, Soja served me warm vegetable soup and sandwiches, stating that it was typical Lenten food; it was February. She explained that when preparing food she always tried to take into account the great fast, but added that dietary restrictions did not, in fact, apply to old people. "I guess I have to concede, at this age, that I belong to that category," she laughed.

The furnishings of Soja's house were a cozy mixture from different decades. On the walls of her living room, kitchen, and bedroom she had hung numerous paintings, decorative plates, and photographs. There were home altars with icons in a corner of all three rooms. The living room was dominated by a massive bureau on top of which stood at least a dozen framed photographs of children and grandchildren. On several occasions during our interview, Soja got up from the living room couch and went over to one of the photographs or icons, showing me a picture of one family member or another, or perhaps an icon she had been talking about. The first such occasion came early in the interview, when I asked her to describe her religiosity. She responded by taking me to an icon that she had inherited from her parents.

Helena: Could you, to begin with, like...describe with your own words, what kind of Orthodox Christian you are? How would you define or describe yourself?

Soja: I'm an ordinary Orthodox [woman]. I've learned this Orthodoxy since I was a child. There, in my kitchen, is the icon we had in our home. It's a largish icon, (...) Saints Sergius and Herman of Valaam. It was placed in a corner like that, with a box where we had candles and other stuff. It was there in the corner of the main room. And in the 
other room we had another icon. Every morning when I woke up I saw my mother make the sign of the cross and pray in front of this icon, before she began her chores. I always woke up to that. ${ }^{1}$

When approaching or touching an icon, Soja made the sign of the cross. I asked her about it, and she noted: "You should always do it. Always. Well, I don't necessarily always remember, but anyway. The sign of the cross is important." Moreover, at one point in the interview, while she was showing me the icons in her bedroom, she suddenly turned to me and asked if I had an icon. I told her that I did, and she continued by asking whether I would like to have another, offering me a small travel icon of Sergius and Herman that she was holding in her hand. I thanked her and took it, surprised as well as touched.

Lived religion consists of practice. In this chapter, I discuss the present-day religious practices of the evacuee Karelian Orthodox women, analyzing their accounts concerning their religious activities to trace the effects of these activities on their habitus. There are several reasons for beginning the analysis with an examination of the interviewees' present-day practices. For one thing, the focus enables me to illustrate, in the different sections of this chapter, the reciprocal dynamic between practices and habitus. In theories of practice, this dynamic is considered central to the very formation of the social world; as a demonstration of its basic functioning, the chapter constitutes an apt of introduction to the overall analysis. Furthermore, the focus also emphasizes the primacy of the present in my discussion as a whole. This book is, essentially, about the religion and the habitus of the women at the time of the interviews. While I spend entire chapters on the past, the ultimate goal is always to disclose something related to the women's religion in the present. According to my theoretical approach, after all, reconstruction of history is necessary to understand present-day habitus. In light of this overall interest, the only appropriate place to start the analysis is in the present.

The interaction of individuals with the surrounding world imbues it with cultural significance. Human action symbolically constitutes the spatial and temporal environment, for instance, as secular or sacred (Bell 1992, 98-101; Munn 1992, 104, 106). The home is one environment layered with significance through religious practice. As anthropologist Thomas Tweed (2006, 81-82,

1 The translations of all interview quotations are mine. From them, I have omitted some repetition as well as any content jeopardizing the anonymity of the interviewees. Explanatory comments are placed in parentheses and missing words in square brackets. Ellipses are indicated with three dots in parenthesis. 
93-98, 103-109) has noted, central to religion are practices of dwelling: practices of "housework" and "homemaking." Often, domestic religious activity has a particularly important role in the religion of women (e.g., Sered 1994, 4-5, 151-153).

The home was the primary setting for the everyday religion of the interviewees. At the time of the interviews, many of them were freer to attend activities outside the domestic realm compared to earlier life phases. Some women had reoriented their religious lives accordingly, participating in church functions more actively than before. For those with poor health, however, the home as a site for religious practice had gained in importance. The women's daily activities included such customs as burning candles, reading religious texts, and listening to spiritual music or radio broadcasts. By far the most common forms of everyday practice, however, were praying, making the sign of the cross, and interacting with icons.

Practices related to religious objects are one form of activity through which the home is transformed into a spiritually charged space. All the women had, at the time of the interviews, at least one icon on display in their homes. Often there were several, of different sizes and motifs, sometimes with an oil lamp hanging in front of the icon and a traditional Karelian käspaikka cloth (e.g., Arseni 1999, 171) covering the frame. The women, overall, considered icons a standard marker of an Orthodox home (see also Fortounatto and Cunningham 2008, 137). To have an icon was "important" and "self-evident"; it "belonged there like a clock on the wall."

During my visits to their homes, the interviewees took me around to see their icons. When presenting icons, they often focused on the icons' history. They recounted how a particular icon had first come into their family and into their possession. Sometimes, they also explained to whom they planned to bequeath the icon. Icons thus connected the women with loved ones and family history, as well as with the religious figure or event that they depicted. Soja, for instance, described her religiosity by referring to an icon that had followed her from her childhood home and now stood in her kitchen corner. It depicted the Saints Sergius and Herman, mythical founders of the Valaam monastery who are honored as "enlighteners of Karelia" in the Finnish Orthodox Church (Parppei 2011, 32-33, 121, 182). The icon linked together Soja's various homes, home areas, and life phases; in addition, it connected her religious practice to that of her mother.

The women regularly lit an oil lamp or burned a wax candle in front of their icons. Some informants prayed or crossed themselves before an icon daily, while others reverted to these practices on special occasions. The most basic interaction with icons, however, consisted of simply looking at, or "resting one's eyes" on them. 
Tarja: And when I come [home] I glance over; the icons have to be placed so that when you enter through the door there is one that you can immediately spot. So, the last thing before I close the door [in leaving], I look [at the icon]. Then, when I return, I always look [at it] first. It has, the habit has become a thing.

In the account above, Tarja describes her habit of looking at an icon when she is about to go out and when she comes home. Her practice echoes the Karelian custom of making the sign of the cross towards the icon(s) of the home altar whenever entering or leaving (e.g., Keinänen 2010a, 131-132). Through her gaze, Tarja accentuates the moment of entering and leaving home, creates a contrast between spaces, and gives a religious significance to the domestic environment and to her own movements with respect to it. More generally, Tarja's account opens up a view into the small and subtle practices that made up the women's everyday religion.

The interviewees described the impact of icons in their daily lives with interesting expressions. Icons "had power," "gave warmth," and "provided safety." They "guided," "reminded," and "spoke to" the women. These descriptions reflect the interaction between the women's socially informed bodies and artefacts symbolically constituted as able to imbue the surrounding space with otherworldly protection and blessing. Icons created a religious dimension within the women's homes. They oriented the informants' attention to spiritual matters. All in all, they evoked responses in the form of feelings, thoughts, and actions - but only because the women's bodies recognized them and were geared to respond to them.

In addition to creating spaces, religious practice can also create time. Religion, in other words, plays the role of both compass and watch (Tweed 2006, 85). Through religious activities, individuals incorporate and actualize particular conceptualizations of time: measurements, rhythms, sequences, and orientations towards past, present, and future (Bourdieu and Wacquant 1992, 137-138; Munn 1992, 107, 116; Tweed 2006, 91-93). The customs of praying and making the sign of the cross provide examples of how the interviewees' religious practice generated temporal markers and organized their daily schedule.

Praying was the most common and regular practice mentioned by the women in the interviews. The women recounted reciting a prayer, or praying in their own words, before going to bed at night, after waking up, and at mealtimes. In addition, they also prayed whenever the situation called for it - giving thanks to God, "sighing towards the sky," or repeating the Jesus Prayer. ${ }^{2}$

2 The Jesus Prayer refers to the short invocation "Lord Jesus Christ, Son of God, have mercy on me the sinner" (Kallistos 2011). 
As to the sign of the cross, most women crossed themselves at home several times a day. It was especially common to make the sign of the cross as part of one's evening and morning prayers, but the informants could also cross themselves before mealtimes or when entering or leaving the home. Generally speaking, the women seemed to consider the sign of the cross the most basic religious act, a miniature prayer. Moreover, as a blessing it was actively used: one could bless oneself, the home, a trip or any kind of endeavor, food, children, and so on. ${ }^{3}$

The women often emphasized their regular observation of the practices of praying and making the sign of the cross: they were repeated "in the mornings," "in the evenings," "every day," "every time," or "always" come a specific time or place. While this may have been in part about presenting themselves as good Orthodox women in the interview situations, the focus on regularity still carries weight. When repeated throughout the day, religious practices give everyday life a spiritual contour, refocusing the practitioner's mindset according to religious frameworks. Simultaneously, they contribute to bringing about particular moments in time. If one recites a prayer every evening before going to bed, the prayer (along with other such procedures) comes to mark "evening" and "bedtime." In this vein, Anna, for instance, exclaimed: "I think that I couldn't start my daily life in the morning if I wasn't allowed to pray!" For Anna, then, prayer was an integral part of her mornings. Essentially, it made her mornings mornings.

\section{Bodies Sensitized to the Sacred}

The constitution of time, space, and whole social worlds relies on the emergence of bodies that can successfully navigate these environments. In and through practice, bodies learn to experience, feel, and act in particular ways. Lifelong participation in Orthodox worship had molded the displaced Karelian Orthodox women's bodies into trained bodies that had the capacity to do religion in Orthodox Christian contexts. One of these contexts was the church.

At the time of the interviews, the most active churchgoers among the women attended the Divine Liturgy of the Orthodox Church several times

3 In the Orthodox Church, the sign of the cross is made by touching the forehead, the waist, and the right and the left shoulders with the right hand, with the thumb and the first two fingers brought together and the remaining two fingers pressed to the palm. The gesture is considered a prayer in itself, as well as a credo, a blessing, and a sign to ward off evil. Often it is described as a threefold blessing: of thoughts, of feelings, and of the labors of the hands (Arseni 1999, 237; McGuckin 2011b). 
a month. Other women, however, participated considerably less often, due to practical reasons (such as health and transportation) or personal preferences. In the interviews, participating in the Liturgy came up particularly often, when I asked direct questions about Orthodox practices important to the women. In answering these questions, the interviewees commonly listed going to church as an essential facet of their religiosity. Moreover, those who were not churchgoers often responded by rationalizing their non-attendance. In spontaneously comparing their own behavior with what they thought (I thought) was the norm, also these women acknowledged the central role of church services in Orthodox Christianity (see also Grdzelidze 2011, 127-129; McGuckin 2011c, 191).

An Orthodox church, especially during the Divine Liturgy and other prayer services, was a place where the interviewees felt particularly close to God and in the presence of the holy. In producing these assessments, they may have been influenced by their ideas of how they, as proper Orthodox Christians, were expected to think. Here, however, I take under analysis descriptions that allude to the social formation of their bodies. That is, I start from the premise that, through a history of attending Orthodox services, the women's bodies had become attuned to the church environment, recognizing it as sacred.

The interviewees, in describing the procedure of attending the Liturgy, emphasized its physical aspects: standing, kneeling, bowing, going forward to light candles, kissing the icons, and making the sign of the cross repeatedly. Standing during services makes them a strenuous physical exercise for those with ailing health. The women explained how standing is tiresome; nevertheless, they did not feel comfortable sitting down, even though chairs are provided in churches for those in need. The habit of standing, that is to say, was ingrained in their bodies.

Elsa: Before, it was considered shameful if a younger person sat, but it's no longer so... sitting is allowed. At least I have to wear really comfortable shoes to be able to stand the whole time, it's very tiring... but you can sit as well. It's about revering God.

Raili: [With the sign of the cross] I show deference to the church. When I go there, I salute that I have come. It's all part of respecting the church. You walk quietly, keep a scarf on, and act calm. The sign of the cross locks you to the reality that you're at church now.

In the above accounts, Elsa remarks on the physical side of standing during services, whereas Raili explains how church as an environment produces a change in her overall bearing: in her posture, in how she walks and talks, and 
so on. The stances, gestures, and styles of movement described by the women are examples of "techniques of the body," learned capabilities that embody cultural standards and regulations (Mauss 1979, 101, 104; see also Asad 1993, 76-77). In the case of Elsa and Raili, the cultural standard consisted of the idea that God, and the house of God, should be venerated.

The visual stimuli of the icons, the smell of incense, and the sounds of recitations and the choir singing were among the various sensory experiences the women highlighted in their accounts. They commonly described these aspects of Orthodox services by referring to their capacity to arouse feeling. A choir singing could sound so wonderful that "you are chilled to the marrow of your bones," or that "you feel your heart go soft." A church could be so rich with atmosphere that "religion is almost palpable" there. More specifically, church services aroused in the women such feelings as "awe," "reverence," "solemnity," and "devotion." Different sensory stimuli all contribute to the constitution of the space of the church and the event of the Liturgy as separate and special. The expressions used by the women suggest that their bodies recognized these elements, reacting to them in the appropriate way.

The interviewees could also bring up the communal nature of attending the Liturgy as important to the overall experience. Senja, for example, explained: "You pray together the whole time. Maybe that's it. You identify with it, that you're one with the others." Alternatively, some informants noted that the hustle created by the crowd actually made it more difficult for them to concentrate on praying at church.

In addition to the crowd of worshippers, the church building and the progression of the service also manifest the existence of a religious community. Sometimes, the women connected their experiences of the holy to these aspects of the church environment. Auli, for example, described how the age of the church building, and the fact that people have worshipped there in the same way for a long time, give it an "aura of prayer." Moreover, the experience of a continuum of tradition was also enhanced by the personal memories that church visits awakened in the interviewees. In this vein, Raili described how the scent of incense at church always makes her remember childhood church visits: "[As a child, the Liturgy] sometimes felt long. But somehow, what stuck with me was I guess the scent of incense. When I go [to church], I find the scent of incense just wonderful. And it brings to my mind such a wonderful feeling." Also Robert Wuthnow (1999, 69-73) has made note of lifelong religious practitioners' vivid memories of the sights, sounds, and smells of their childhood places of worship.

The above examples show how, for the women, different aspects of the church environment (church architecture; visual, vocal, and olfactory stimuli; physical stances and activities; intersubjective encounters and the sense of 
collectivity; as well as the rituals themselves) connoted the special nature of the Liturgy. They marked the occasion as sacred, evoking feelings of awe and respect. The interviewees, on the whole, explicitly commended the Orthodox Church for its capacity to differentiate sacred times, places, and situations from ordinary ones. However, from the perspective of practice theory, the women's ability to experience the holy in Orthodox church functions was a talent acquired through a history of churchgoing.

Embodied religious practices induce in practitioners the skill to perform actions, have experiences, and feel feelings appropriate for the situation in question (Asad 1993, 76-77; Bell 1992, 100). Respect for God, for instance, is not a naturally occurring inner state which you then express by standing in church. Instead, through practicing the act of standing in church the individual as a respectful and subordinated churchgoer is produced. Through such "sacralizing practices" (Martín 2009, 280-283; Trulsson 2010, 63), the women's bodies had sensitized to the event of the Liturgy. They had the ability to respond to the church environment and the rituals conducted with corresponding acts, sensations, and emotional reactions.

The interviewees' "practical mastery" (Bourdieu 199ob, 66, 102) of the practice of participating in the Liturgy is also reflected in their descriptions concerning its effects. They often emphasized going to church as an experience of being reinforced in one's faith. The Liturgy "deepened" one's spiritual knowledge, induced "development" as a person, and offered "nourishment," "strength," and "remedy" of self. These expressions, once again, adhere to common Orthodox discourse. Nevertheless, the women's descriptions may well reflect their genuine experiences. To the individual whose body is attuned to the specific context of Orthodox Christian church life, participating in the Liturgy can be a holistic experience of recognition. It engages and activates one's embodied memories, senses, and capacities as a religious practitioner, acting as a reminder of one's faith.

The preceding discussion, all in all, makes evident how the displaced Karelian Orthodox women's religious customs functioned as world-making activities. The women's actions, in their daily lives and in the church environment, transformed space and time, altering the symbolic structuring of their world. The self, however, is where this process actually takes place. The women's activities constituted "self-processes" (Csordas 1994, 5, 276-277), which organized their senses, predisposed them towards certain ways of feeling, knowing, and acting, and orientated their outlook on the world (see also Mellor and Shilling 2010a, 30; Mellor and Shilling 2010b, 202). In other words, the activities were about the embodied acquisition, reinforcement, and living through of their habitus. 


\section{Habitual and Intentional Practicing}

In the interviews, the women emphasized the constancy of basic religious practices in their everyday lives. The unproblematic status of these customs was underlined by expressions such as "natural," "obvious," "self-evident," "automatic," and "routine." With these kinds of descriptions, the interviewees suggested that the observation of the practices did not require deliberation. They simply felt like the right thing to do. Indeed, it was not uncommon for the women to express an inherent sense of obligation, urgency, or inevitability accompanying these practices. Senja, for instance, explained that she was incapable of not crossing herself when she woke up and before going to bed: "It's been wedged into my head; I can't help doing it." Toini was on the same track: "You can't make a list of occasions for making [the sign of the cross]. When you need it, it comes naturally."

Senja and Toini describe their practice of making the sign of the cross as something that is not thought through on a discursive level, but depends on their embodied command of particular environments. Both women's accounts can be understood to depict the practical sense guiding their observance. When an individual comes into contact with a familiar environment or situation, he or she tends to experience certain actions as necessary and natural. The experience results from these practices having been a means of past structuring of the individual's habitus. The actions have a "claim to existence," because they are the very form through which the self takes his or her place in this particular environment (Bourdieu 199ob, 53-54). The interview material suggests that, in their basic religious activities, the women relied mostly on their sense of practice. Many of them described these practices happening as if of their own accord. Lived religion, overall, often builds on such routinized practice.

Routines change, however; and the women also spoke of basic religious practices losing relevance. Some customs that had earlier felt self-evident, were no longer so. Instead, these customs were "waning," "slipping," or "melting away." Faina, for example, noted that making the sign of the cross "has almost become an evening duty. Sometimes [I make it] at the beginning of a meal, but I don't always remember. Yes, these customs are slackening!" The expressions used by Faina and others also describe their sense of practice. Only, due to the evolution of their dispositions, this sense no longer signaled the necessity of observing certain customs. That is to say, the women did not necessarily consciously choose to discard a certain practice. After a long enough history of situations that did not support its use, their habitus no longer imbued it with the same urgency as before. 
Studies on the religion of individuals whose religious involvement has, in one way or another, changed during adulthood often focus on the active cultivation of piety (e.g., Brahinsky 2012, 229-231; Mahmood 2005, 122-131; Winchester 2008). Through intentional practice, novices work on molding their dispositions to match their new vocation. The goal is to make the chosen way of life part of spontaneous and habitual behavior. The women of my study rarely spoke of this type of conscious devotions. Nevertheless, neither was intentional practice completely alien to them.

One of the main ways in which the women took up the topic of intentional practice was through speaking of remembering. Similar to Faina (above) and Soja (in the introductory vignette), they regularly applied the verbs "remember" and "forget" to describe their religious observation. Some customs they "always remembered" to follow, whereas others they "sometimes forgot" or had "recently started to forget." The interviewees also emphasized the importance of remembering to practice: to pray, to give thanks to God, to quiet down during Sundays, to remember one's deceased relatives, and so on. Through this kind of talk, they acknowledged that the observation of everyday practices did not actually always happen by itself. The emphasis on remembering suggests conscious effort in keeping up religious activities and a religious mindset.

Even the most stable of the evacuee Karelian Orthodox women's religious habits had undergone some changes over the course of their lives. Some customs had been subjected to particularly drastic changes. One such cluster of activities was related to the organization of time cycles longer than a single day. While the liturgical calendar is an important part of Christian worship, religious notions of time do not necessarily hold the monopoly on timereckoning on a societal level. In pre-modern Orthodox Karelia, the agrarian lifestyle accommodated the major elements of the Orthodox liturgical calendar (Repo 1979). ${ }^{4}$ Modern Finnish society, in contrast, is organized around temporal cycles reflecting the demands of industry. Only the biggest of the Christian feasts are included in the civil calendar.

At the time of the interviews, those women who were churchgoers often attended church on Sundays. The women might also follow broadcasts of (Orthodox or Lutheran) church services on TV or the radio, or consecrate church-time by burning a wax candle in front of an icon on Sunday mornings. The interviewees emphasized, moreover, that they were always mindful of

4 The Orthodox liturgical calendar revolves around the differentiation between ordinary time, feasts, and fasts (McGuckin 2011a). Wednesday and Friday are considered fast days, whereas Sunday constitutes a minor feast in itself. The most important annual cycle of feasts concentrates on the Easter mystery. The calendar includes four longer fasts, which all precede important feasts (Conomos 2011; McGuckin 2011e). 
Sunday being a "special day." In contrast, when speaking of childhood Sundays, they commonly mentioned a number of concrete activities demarcating the special nature of the day. On Saturdays, the house was cleaned and the family went to sauna. On Sundays, people wore special clothing, ate special food, and suspended all non-essential work. In addition, the family either attended the Liturgy, listened to what was usually a Lutheran service from the radio, or at the very least behaved in a respectful manner during church hours.

The interviewees' descriptions of childhood customs, it must be noted, often conveyed a tone of nostalgia. In addition, for some of them the interview situation was mainly an opportunity to remember childhood religion - a starting point that created additional contrast between depictions of childhood and present-day practices. In any case, the women's accounts point to an important difference. Whereas childhood accounts revealed the regulative nature of concrete practices, in descriptions of the present the focus was more on the awareness of Sunday being a special day.

The diminishing significance of the religious organization of time was traceable also from the women's accounts concerning the annual cycle. While some of them emphasized that attending Divine Services regularly interviewed their lives with the Orthodox liturgical year, others kept an eye on the progress of the liturgical year more cursorily, for instance, with the help of a calendar or the parish bulletin. Overall, even though the interviewees recognized the value of different midweek holidays and commemoration days in creating variation to religious life, their observation was mostly considered an optional extra. The major church holidays, by contrast, continued to provide an annual rhythm to the women's lives.

Easter and the preceding Lent formed the focal point of the year in the women's religious lives. The interviewees stressed that during Lent they tried to go to church more frequently than during other times. Also other practices, such as fasting, demarcated the period as special. Fasting constitutes an embodied disciplinary activity par excellence. Moreover, it is an interesting practice also from a gender perspective, since food preparation in families often lies with women (e.g., Turner and Frese 1999, 346-347). The women's descriptions of the great fast reveal changes in their dispositions between childhood and today, suggesting the evolution of fasting from habitual to intentional practice.

In the childhood families of the women, the Easter fast was observed in different ways. Generally speaking, oldest family members were the strictest in their fasting. The interviewees' parents, however, did not necessarily observe a full-scale fast. While in some families children were required to fast for the whole seven weeks, in others they fasted for Great Week or Good Friday only, or did not participate in the fasting at all. Small children are exempted from the Orthodox fast (Paavola 2007, 29); nevertheless, the women's accounts allude 
to fasting practices having already been in a process of change during their childhood. At the time of the interviews, the informants continued to observe Lent in one way or another, but few fasted in the traditional style. Furthermore, those who changed their eating habits might do so just for the duration of Great Week or Good Friday. Like children, the infirm are also spared from fasting, and a few of the women openly counted themselves among this category.

The women often noted that as a child fasting had not been difficult. It was simply about eating the same food as others. At the time of the interviews, however, the informants found fasting challenging. There were so many temptations around. In addition, they lamented that taking into account the eating habits of others - either as host or as a guest - easily made one break fasting regulations. Since childhood, the women had spent several decades preparing food for their mostly Lutheran husbands and children. In the Lutheran Church, fasting regulations are not emphasized in the same extent as in the Orthodox tradition (see Kirkkohallitus 2009, 51).

Senja: This Easter I had visitors for the whole time, from the other [Church]. At these times, it recedes [to the background], you start slipping. (... ) You must cook for those who know nothing about fasting... Then, you slip. But I remember when I was young and worked at a canteen, I spat it out. You have to taste everything [you cook], but it (fasting) was so firmly in the back of my head that I couldn't swallow [the food].

Senja's account illustrates well the evolution of fasting from a self-evident and habitual to a more intentional procedure. In Senja's youth, keeping the fast was what her sense of practice deemed necessary, so much so that she "couldn't swallow" food that went against the diet. At the time of the interview, the priority was being a good host. In the company of people who did not observe the fast, it was often forgotten. Similar to Senja, also other women noted how they nowadays made fewer changes in their diet, and how it required a conscious effort to comply with them - even though the awareness that Lent "was not just any time of the year" had stayed with them since childhood. Some of them, moreover, explained that their fasting consisted solely of a spiritual fast. By this the interviewees meant a quieter overall lifestyle, and particularly the aim of not causing others any harm or bad feelings. ${ }^{5}$

5 The dietary restrictions of the great fast involve meat, fish, eggs, and dairy products. In Karelia, dried fish was part of the diet also during this period (Merras 2006, 85-86). According to Orthodox thought, dietary fasting should always be combined with an overall orientation towards religion (Binns 2005, 137-138; Conomos 2011). The term "spiritual fast" refers to the 
The examples discussed here depict the receding role of embodied practices in the women's religion. They describe situations in which the observation of practices was no longer automatic, but had to be consciously willed. Moreover, they indicate a shift of emphasis from practices themselves to an awareness of what the customs supposedly represented. Rather than making Sundays or Lent special times through concrete practices, the women focused on being mindful of the special nature of these times. This suggests that their activities had been affected by a process of metaphorization. Metaphorization, Talal Asad (1993, 78-79) explains, constitutes a development in which embodied religious rituals lose their function as practices geared to induce particular dispositions in the practitioners. Instead, the rituals become "representations of cultural metaphors." The process, Asad notes, makes religious customs more susceptible to displacement, since metaphors are always open to different interpretations, whereas dispositions are rooted in practicing bodies. According to Asad, metaphorization is a by-product of modernization. In the case of the Finnish Orthodox community, however, Lutheran influences have likely accelerated the process (see also Heikkinen 1989, 332-333).

All in all, the interviewees' descriptions of habitual and conscious practice, as well as awareness as a form of practice, betray changes in religious customs. These changes (from routine to intentional and from embodied to mental) can be understood as evidence of the long-term evolution of the women's embodied dispositions, of their habitus. The specifics of this evolution become clearer in the course of the next two chapters where I discuss the historical formation of the women's habitus; here, my aim has been to describe the intertwinement of their present-day practices and habitus. Moreover, when evaluating my interpretations, one must keep in mind that the interview material is a product of the informants' current habitus. Thus, it provides only one verbalized version of the women's past experiences of practice.

\section{Describing "Orthodox" Practice}

Previously in this chapter, I have occasionally remarked on the influence of the interview context on the women's accounts. Here, I take under analysis the interview situation as such. My starting point is the idea that the women's accounts bring out some of their practices of speaking about religion: practices that also reflect their habitus (see Bender 2012, 278-279).

abstaining from secular pursuits and past-times, and to the adoption of an altogether more austere lifestyle for the period of the fast (Serafim 2006, 11-22). 
In the interviews, the displaced Karelian Orthodox women presented a somewhat varying take on doctrinal issues. While some interviewees spoke on the topic with confidence, many were not comfortable doing so. The women in the latter group may have felt that they lacked authority to address such themes face-to-face with a specialist of religion, even though I impressed on them that I was not a theologian (see Bourdieu 1991b, 54-56, 72-76). Sometimes, my questions also problematized issues that for the women were self-evident.

Helena: Can you describe, what making the sign of the cross signifies or means to you?

Lempi: Both that when you bow you show respect to Christ and to His gospel, suffering, [and] death. And that you kind of receive a blessing on your handiwork and on your human being, thoughts, [and] feelings. It has an immense symbolism.

Katri: Well, what does it signify? What does pressing one's palms together signify for Lutherans? ( . . ) I can't explain what it signifies.

Rauha: Well, I don't know. I feel that it means all things. Like when you say "triune God," it [is] something that means all things, yes ... This is my view.

Above, Lempi speaks confidently of the meanings of the sign of the cross. Katri is somewhat indignant at my question which she finds exoticizing and condescending. Rauha responds by a cryptic comment that the sign of the cross means "all things." In their interviews, both Katri and Rauha expressed an apprehension with regard to doctrinal issues; Katri even noted that an analytic approach to religion was "just like picking a daisy and [plucking] its petals." Lempi, for her part, was one of the more theologically articulate informants.

Verbal interpretations are only one form of knowledge about practices. In fact, practice inscribes the bodies of practitioners with cultural meanings directly, irrespective of conscious reflection taking place (Bourdieu 1977, 94-95). Robert Wuthnow (1999, 165) notes, of individuals who have grown up religious, that they usually have a practical understanding of spirituality. This applied to my interviewees as well. Katri's and Rauha's accounts convey well the difficulty experienced by many of them when asked to interpret customs that they understood first and foremost on the level of the body.

According to Bourdieu (1990b, 102-103; 1977, 17-19, 37-38), formal interpretations of practice cannot capture the actual logic behind the generation of practices. Individuals act following their sense of practice, not explicit 
rules or abstract principles. Nevertheless, rules, principles, and grammars are typical ways for practitioners to conceptualize their actions. In this vein, also the Orthodox women explained their practices in the form of rules: "you must," "you have to," "you cannot," and so on. However, these kinds of expressions did not mean that they actually followed the rules they evoked. On the contrary, they often acknowledged that the rules did not govern their activities in the way they, in theory, should have. Elvi, for example, explained: "For instance, when you approach a grave, you make the sign of the cross. And you're supposed to make it when you come inside. But I don't always make it when I come home."

There exists, overall, a copious amount of more or less authoritative interpretations of Orthodox Christian practices. The interviewees have encountered such interpretations at home, in school, in church functions, and in the media. They have been taught them by relatives, teachers, peers, religious experts, and public figures. When explaining their customs in the form of rules the women drew from these different sources. They backed up their accounts, for instance, by stating "my mother taught me," "a priest has said," or, when evoking the authority of theological tradition on a general level, "it is said" or "it is the Orthodox way." Furthermore, reference to existing rules seemed to come instinctively to them. It was how one was supposed to respond to inquiries about customs.

Taken as such, the interviewees' tendency to speak of their activities as rulegoverned can be viewed as evidence of their blindness regarding their practice (Bell 1992, 82, 87, 108-109). However, as I established above, the women often acknowledged that their customs were actually more flexible in character than the rules suggest. Moreover, besides citing existing sources they could also take a more reflective, or even questioning, stance towards rules. Toini, for instance, stated: "When I had children, I remember mother saying that I have to go to church to be blessed or something. That after giving birth one was unclean. Well, I rebelled against that, I said that it can't be so." ${ }^{6}$ And Vieno reasoned: "I have to be honest and say that the previous home, it was just left, left and left, unconsecrated. But... we spoke about it with mother that, well ... it surely becomes blessed if one attends church regularly and remembers to pray and the like." ${ }^{7}$

6 Toini is referring to the ritual of churching, traditionally held on the 4oth day postpartum, in which the mother is cleansed of the ritual impurity caused by childbirth (Limberis 1999, 753; McDowell 2011, 572). According to church historian Ritva Saarikivi (1974, 94), the custom was already on the wane in inter-World War Border Karelia, at least in the region of Salmi.

7 Vieno is speaking of the ritual blessing of the home, conducted by a priest, commonly organized when moving into a new house or apartment (Merras 2006, 77-78; Pettis 2011). 
In addition, it was not uncommon for the women to label their interpretations as personal opinions, to distance them from any official discourse. The frequent use of expressions such as "in my opinion," "I find," and "to me" is a practice of speaking about religion that complies with the modern emphasis on individuality. That the focus is on the speaker's point of view does not automatically guarantee that what is stated is a product of thorough reflection. However, many of the women's spontaneous remarks, like Vieno's comment above, indeed testified to their capacity to reinterpret and modify existing grammars of religious practice.

Overall, the interviewees' use of language suggests that they were familiar and could engage with various discourses concerning religion. Their most profound knowledge of religion, however, seemed to have been more practical in nature. In place of all-encompassing, coherent explanations, they dispensed partial and provisional insights into their religious activities (see also Wuthnow 1999, 164-166). In fact, from the women's point of view it was not even possible to produce full-blown verbal accounts of religion, as religion was rather about embodied practice. Thus, many of them were uncomfortable with analyzing their religion overmuch; a wariness that shows, for instance, in Auli's, Martta's, and Sinikka's accounts, below. The three informants' replies to my question about a particularly important Orthodox custom underline how, for the women, religion was not a conglomeration of individual practices. It was a way of life.

Helena: Well, is there some Orthodox custom or ritual that is particularly important or dear [to you]?

Auli: No... Nothing is so terribly [special]. To me, it's a totality. It also always varies what you at any time $[$ prefer $] ..$.

Martta: It's all so obvious, because you've belonged to it (the Church) since a child. So you can't pinpoint anything.

Sinikka: I can't really say anything to that. Somehow, this is everyday life.

Furthermore, the example above also brings up an important condition of production of the interviewees' accounts. Religious traditions such as Christianity or Islam are not empirically accessible objects (Beckford 2003, 21; Riesebrodt $2010,19)$. In the study of lived religion, the realization that definitions of religion and religions are always partial has led to an emphasis on articulated beliefs and practices instead of abstract systems (McGuire 2008, 4; Orsi 1997, 7). 
In the interviews, however, I repeatedly spoke of "Orthodoxy" and "Orthodox" practices. That I did not see a problem with this at the time bespeaks of my own majority position within the Finnish religious field. I instinctively viewed the women as representatives of Orthodoxy. Had I interviewed Lutheran women, I would likely not have underlined their affiliation in the same manner.

One way in which the interviewees reacted to my categorization of them as "Orthodox women" was by stressing their church-oriented activities. The focus conjured, in their minds, a normative idea of an Orthodox person against which they measured their behavior. In some ways, then, the setting may have led the women to answering questions as representatives of their religious community, instead of speaking from the basis of their personal experience. Moreover, it may also have discouraged them from mentioning some of their more eclectic practices and beliefs to me.

Helena: I already told you, and you've probably heard it from N. N. as well, that I've been searching specifically for Orthodox women to interview. So, would you tell me first, or describe, what kind of an Orthodox are you? If you had to describe it somehow?

Lyyli: I'm just a normal person. I don't think at all that [I am] Orthodox, I'm just a normal person ... Like I said on the telephone, I'm not a believer, but still I don't dare do bad things (laughs). I always try to do good rather than bad.

For some women, my emphasis on their Orthodoxy was clearly baffling. After all, religious activity rarely focuses first and foremost on the conscious performance of a particular tradition. Lyyli's response, her emphasis on her normality, also highlights the orientalism inherent in my question. However, even as some interviewees shunned from my focus on the category of Orthodoxy, others (similar to Soja in the opening vignette) were fully at ease with it. The interviews of these latter women brought out their conscious Orthodox identity. It surfaced partly as reaction to my prompts, but also spontaneously, like with Hilja, below.

Helena: Could you tell, here in the beginning, a little about your childhood home? And about the kind of family you were born into and the kind of situation?

Hilja: I was born into an Orthodox family. I have an older sister and then there's me and then there are two younger brothers. The family was Orthodox and lived every day like the Orthodox Church had taught. 
No single factor explains this variation in the women's accounts. Lyyli's and Hilja's life trajectories, for instance, were fairly similar in that they had been born less than five years apart and had both married Orthodox men. Nevertheless, emphasis on the category of Orthodoxy is a feature of the interview frame that is important to keep in mind throughout the analytical chapters. The interviewees have produced their descriptions and assessments, at least in some regard, in response to my labeling them as "Orthodox women."

In this chapter as a whole, I have analyzed the women's accounts concerning some of their individual religious customs, to illustrate the mutually constitutive relationship between their habitus, religious practices, practices of speaking about religion, and the surrounding environment. The discussion has produced a baseline account of the interviewees' religiosity upon which I build the following chapters. At the most basic level, the women's religion was precisely about their concrete, daily religious activities. These customs sustained also their more elaborate perceptions, appreciations, and experiences concerning religion. 